Brenner 腫瘍を併存した linitis plastica 型胃癌の 1 例

岩手医科大学第 1 外科

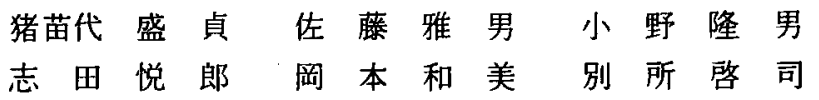

\title{
A CASE OF GASTRIC CANCER (LINITIS PLASTIBA) ASSOGIATED WITH BRENNER TUMOR
}

Morisada INAWASHIRO, Masao SATO, Takao ONO, Eturou SHIDA, Kazumi OKAMOTO and Keigi BETUSHO

lst Department of Surgery, School of Medicine, Iwate Medical University, Morioka. Japan

linitis plastica 型胃癌は, 本邦においては胃癌の10\%程度の頻度である Borrmann 4 胃 癌の一種であり，比較的稀なるのであろう. Brenner 扸瘍は Krukenberg 隀痬を除く卵巣

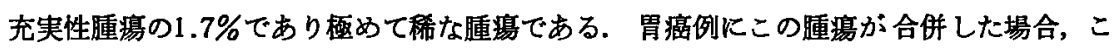
れを Krukenberg 尰湯と判断して胃癌に対し非治窑手術又は姑息手術を施行してしまう危 険がある. 著者らす，64歳女性の linitis plastica 型胃癌症例に Brenner 隀痬が合併して いたため, 初め Krukenberg 尰煌と診断した例を経験した. 胃癌, とくに linitis plastica 型胃癌に Brenner 尰湯が合併した報告は殆んどみられないので, 若干の知見を加え, 報告 する.

\section{はじめに}

卵巣の充実性腯湯は稀であり最む多いのはKrukenberg

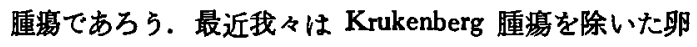
巣の充実性腫瘍の1.7\%と報告される Brenner 腫芴を経 験した. 本症例は linitis plastica 型胃癌であったため, Brenner 腫湯ははじめ Krukenberg 尰瘍と診断され胃全 摘術に $\mathbf{R}_{3}$ のリンパ節原清を行ったにすかかからず, 手 術は完全非治落手術と判断された. 後に組織学的検索に より Krukenberg 腫痬ではなく, Brenner 腫瘍と診断さ れたため手術は完全治瘾手術となった. linitis plastica 型胃癌す比較的稀であるが Brenner 腫瘍むさらに稀であ り両腫掦が合併した報告は殆んどみられない，Brenner 尰湯は悪性腫渴に類似した外锶を示す場合もあり, 本尰 湟が胃癌に合併した場合, これを Krukenberg 腫湯と判 断し胃癌に対する治瘾手術を放棄する危険がないともい えない. 自験例に若干の文献的考察を加点て報告する.

\section{定例}

者: 64歳, 女性, 主婦.

主培：食後胃部膨满感, 体重減少.

家族歴：両親とも脳出血で死亡.
既往歴：30年前に虫垂炎で虫垂切除.

現病歴：約 1 年前から食後胃部膨満感があり, 通常の 食慨量を摄取するのか涃難となる. 食䬣量が多いと呕吐 をする. 約10カ月前某医を受診し胃下垂症として投薬を らけるが愁訴改善せず転医. 同医より本学放射線科を紹 介され入院. 1979年 4 月, 手術の目的で外科へ転科とな る.

入院時現症：“るいそう”が目立ち皮フは乾燥してい る. 心窝部に弓形棒状の可動性がある腫瘤を触知する. 王痛はない，肝，脾，留等を触知せず腹水貯溜の所見を 認めない. 胸腹部に聴打診上異常はない.

臨床検查所見 : 赤血球, $322 \times 10^{4}$, 白血球, $5.4 \times 10^{3}$, $\mathrm{Hb}, 9.6 \mathrm{~g} / \mathrm{dl}, \mathrm{Ht}, 27.2 \%$, 血小板, $225 \times 10^{3}$, 白血球分 画のうちリンバ球は $28 \%$, IgG 1,202mg/dl, IgA 91mg/ $\mathrm{dl}, \mathrm{IgM} 68 \mathrm{mg} / \mathrm{dl}$ と免疫グロブリンの低下をみ，PPD 皮内反応は $12 \mathrm{~mm} \times 12 \mathrm{~mm}$, 発赤は軽度で水疱はない。

X㮩所見：胃透視所見では胃体部の狭小硬化，破壁の 肥大，喷門下部小弯の腫瘤陰影がみられるが，明らかな 尰瘤陰影ではなくBormann 4 型胃癌の診断である. 左 胃動脈造影で胃体部，胃底部の大小弯に血管のコイル状 
短維，硬化，壁不整がみられ静脈巣でのうっ滞がみられ る. 食道壁にはX線上異常がないと診断した，腎孟造影 で左腎が造影されない，レノグラムでも左腎の機能廃絶

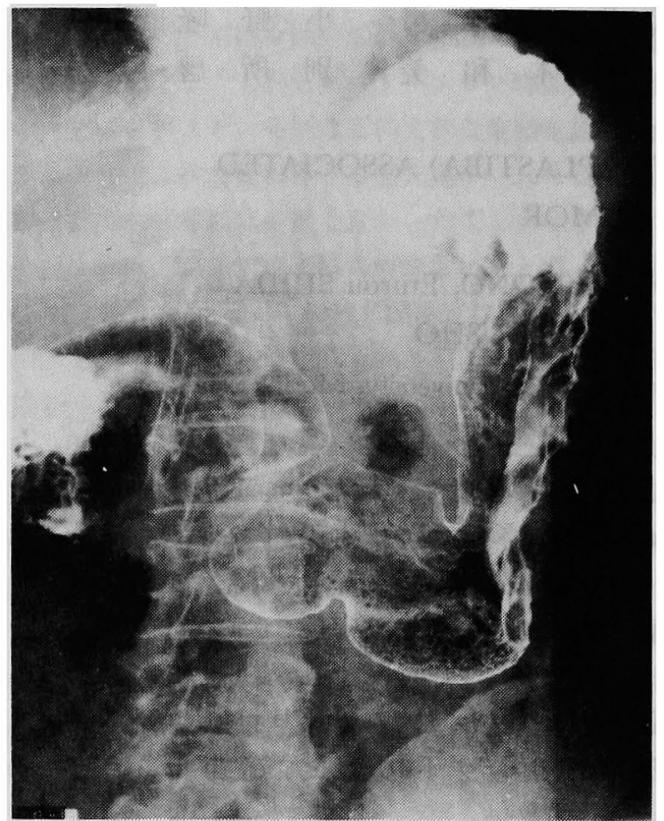

写真 1 胃二重像影（発泡棌使用）

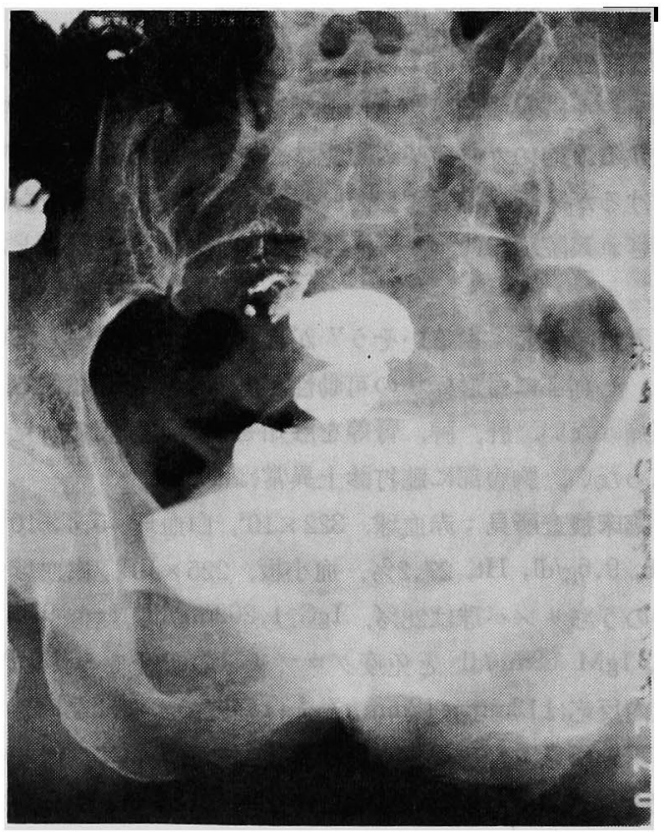

写真 2 堅杰造影後膀胱部レ線写真写 (注腸後の: リウム遗残がある)
をみる．留昷造影を利用した膀胱造影では膀胱右上縁の 硬く水平な圧迫像が双られる（写真 1，2）.

内視鏡および生検所見：䏢壁肥大が胃体部全体を占め 送気に上る胃の膨みが悪いため，部分的には隆起性にも みえる. 体部前壁小弯に浅い潰湟がある. 食道壁に内視 鏡上異常所見はなかった，生㭘標本では胃粘膜上皮の 過形成があり潰場周辺から採取した 8 ケのうち 4 ケに Group IVの異型性がみられた。

手術所見：上腹部正中切開を䐗下に延長して開腹, 腹 水の貯溜はなく $\mathrm{S}_{2}, \mathrm{H}_{0}, \mathrm{~N}_{2}$ の所見で，Pについては右

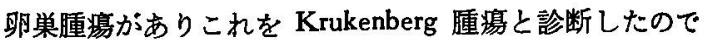
$\mathrm{P}_{2}$ となり Stage IVであった，胃の外形は略正常である

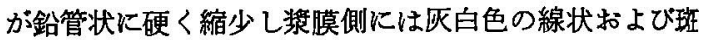
点状の肥厚がZられた，胃結腸内膜の線維性肥厚短縮， 前後葉の癋着がみらられたがその中心部に過去に横行結腸 から穿孔遊離したと考えられる長さ $4 \mathrm{~cm}$ の魚骨が埋没 し，癋着はこれによる反応性のるのと考えられた，手術 は胃結腸間膜の前葉, 膵被膜, 後腹膜を切除し, 胃全摘 術に $\mathrm{R}_{3}$ のリンパ節遊清を併施した，空腸 $40 \mathrm{~cm}$ をすっ て食道，十二指腸間に interposition 法を行って消化管 の再建を行った．次いで右卵巣腫堭に対し卵管卵巣切除 を行った．卵巣腫瘍は手拳大で周囲との痹着はなく灭白 色, 結節性硬であった。

切除標本所見 : 小弯側て切開，䁶壁肥大 を占居する．明らかな潰瘍や腫瘤病変はないが，体部前 壁に $1 \mathrm{~cm} \times 1 \mathrm{~cm}$ の周团と色調の 異るビラン性変化があ るが，胃小区の構造は保たれている. この部之肉眼的に 連続性はないが噴門部から食道にかけて浅いビランがあ る. 割面では胃壁各層の構造は良く保たれている（写蒖 3 ).

卵巣腫湟は灰白色，凹凸不整結節状であり結節の大小

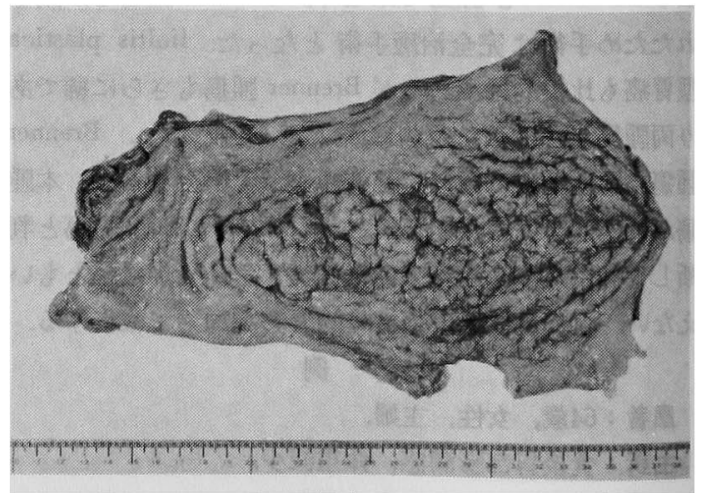

写真 3 （切除胃標本，ホルマリン固定後） 


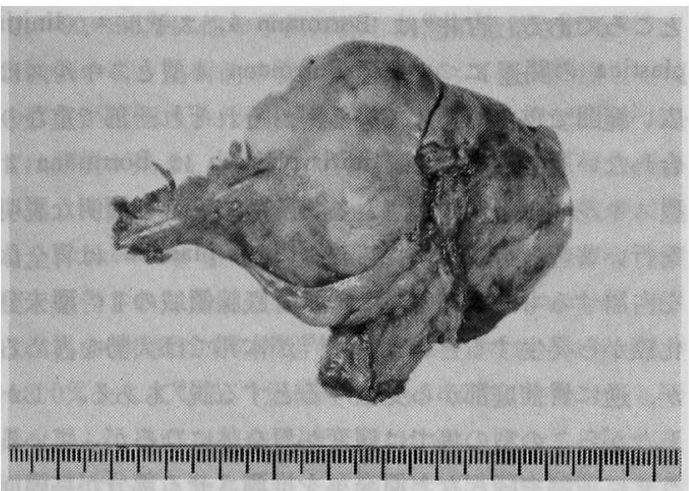

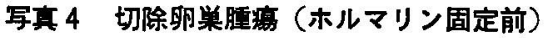

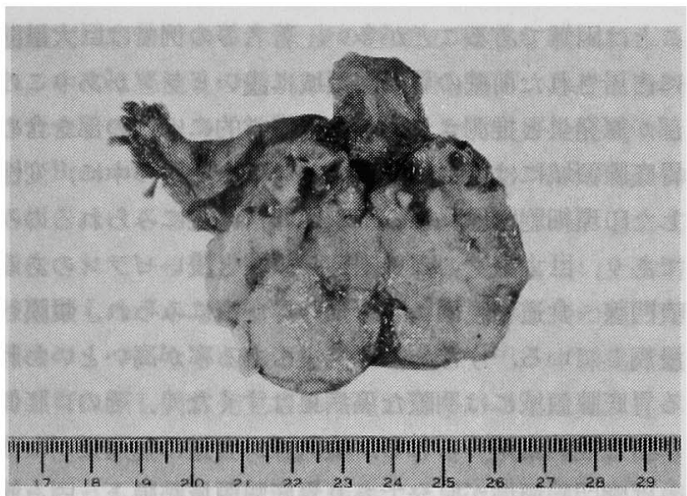

写真 5 切除卵巣霾瘦（割面）ホルマリン固定前

る不同である.極めて硬く，メスにより割を入れる際に す強い抵抗を有する．割面は充実性均質であり所々に浅 い董尰状の陷凹や灭色〜白色の色調の变化，壊死状の部 がみられる. 液眝溜はみられない（写臬 4，5）。

病理組桟学的所見

胃 : 組織学的にも胃壁各層は明瞭に識別される. 粘膜 上皮は高度の過形成を示すが，この部に異型細胞はみら れない（写真 6)．粘膜下層，固有筋層は肥厚し結合織 の増生が著しい.この部に泡沫細胞に類似した印環細胞 の変性した細胞と思われるむのが非常に疏にではあるが

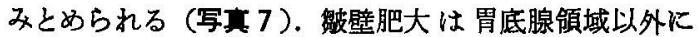
はみられないがこれら幽門腺領域，噴門腺領域には印環 細胞が滵に存在し将膜への浸潤がある（写真 8 ）. 幽門 腺領域では癌巣の表面を薄い再生上皮が覆っている，粘 膜上皮の過形成，粘膜下組織，固有筋層での結合織の增 生は胃底腺領域以外ではみられない。

卵巣，豊富な線維結合織の增生の中に特徵ある上皮細 胞巣が種々の形でみられる，細胞は明瞭な核小体をるつ 円形核と明るい細胞質からなり扁平上皮に似る配列をみ

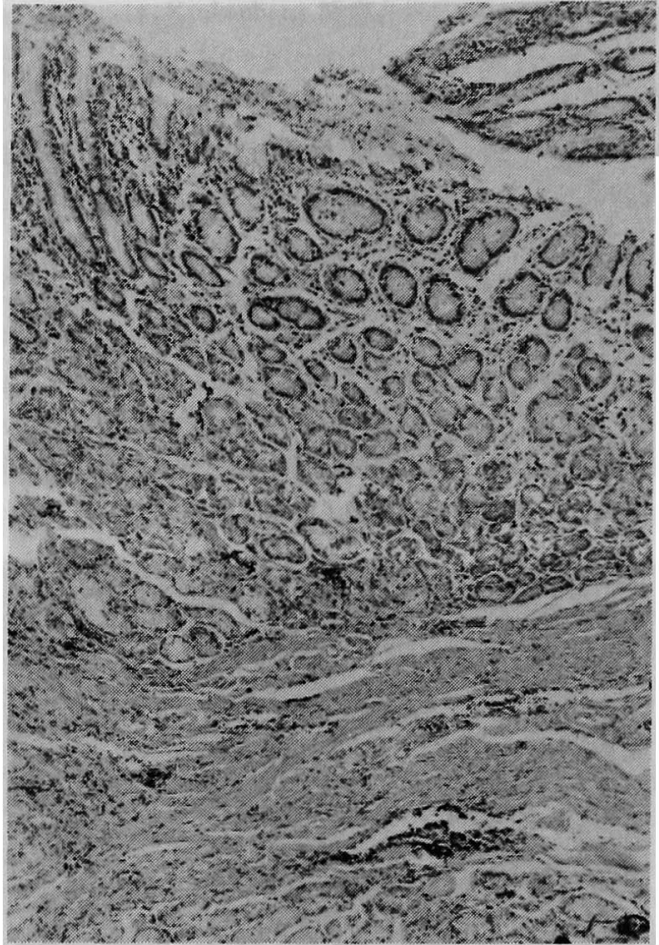

\section{写真 6 胃病理組織所見（胃体部） H.E 染色}

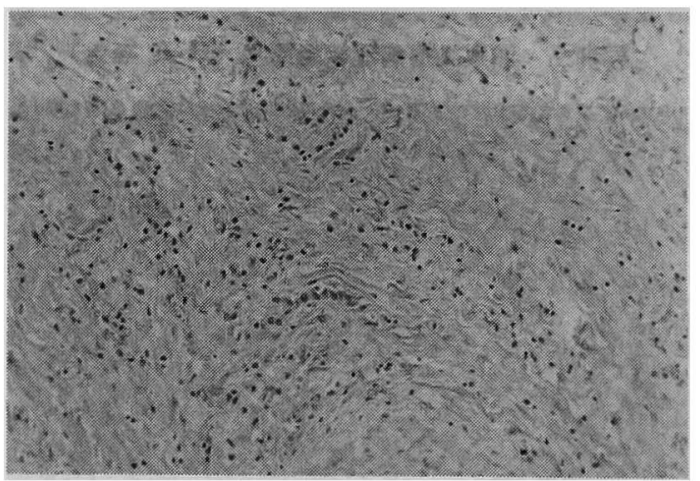

写交 7 胃病理組緎所見（胃体部粘膜下局） H.E 染色

る. 上皮巣の中央部には葆胞化やそれへの移行を思わせ る部分がみられ，鸾胞の境界は変形した細胞の配列から なる膜状構造をみる（写真 $9 ， 10 ）$.

\section{考案}

linitis plastica は1859年 Brinton によって報告されて いらいBrinton 病ともいわれ硬化縮少した特殊な胃炎性 変化として位置づけられていたが，のちにこれは特殊な 型の胃癌であり，その多くは Konjetzny の分類による 


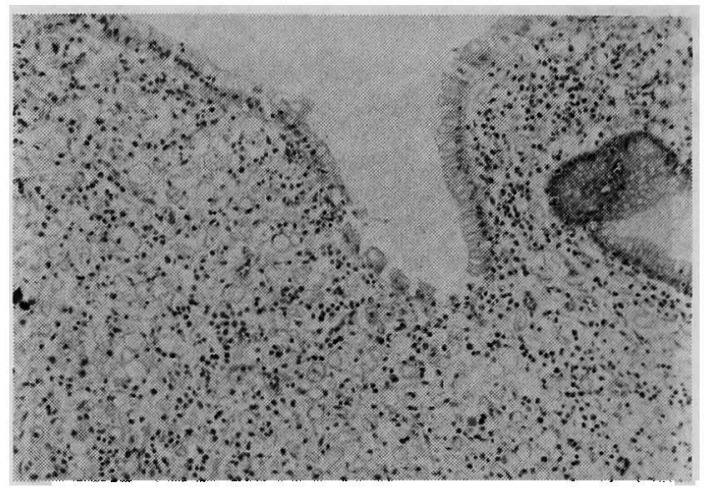

写奥 8 胃病理組樴所見 (胃幽門前庭部) H.E 染色

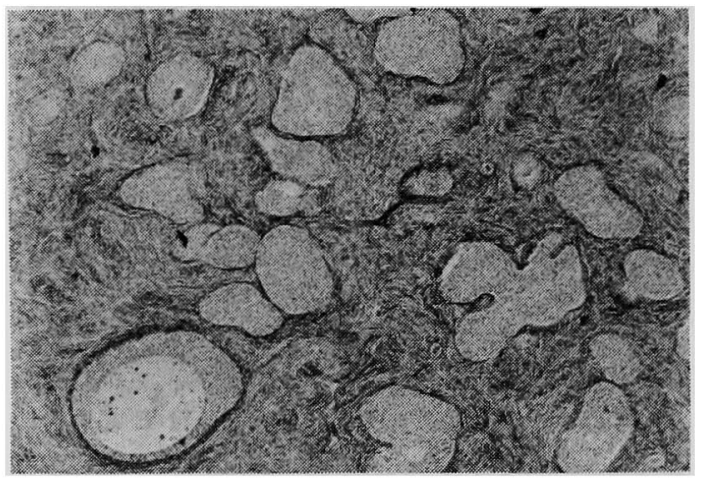

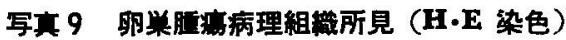

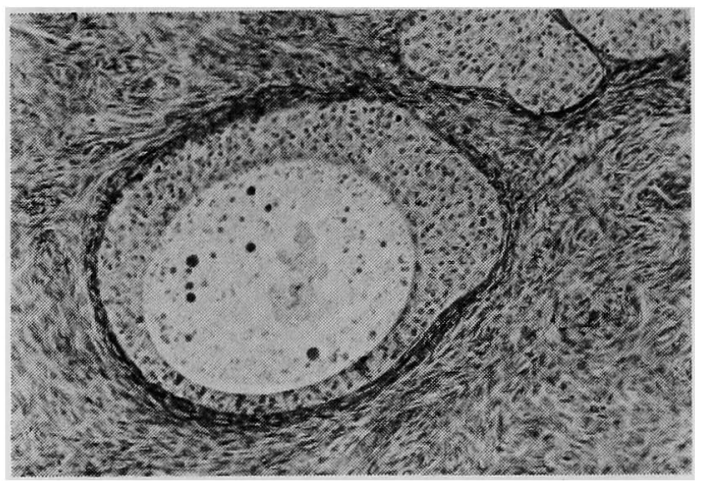

写真10 同（拡大）

Ca. fibrosum に属するものと考元られるようになった. しかし今日のように症例が多くなると中には必ずしむ この定義に包括されるものばかりではなくみられること から Borrmann 4 型, スキルス, linitis plastica, diffuse carcinoma 等の様々な名称で表現される場合があり， 第29回の胃癌研究会1飞おける全国施設からの発表です 同様の傾向をみ明らかな difinition が必要とされている
ところである. 吉井 ${ }^{2)}$ は Borrmann 4, スキルス, linitis plastica の関連について, Borrmann 4 型とスキルスは 広い範囲で重なりあっているが，それぞれ一部で重なり 合わない所があること. linitis plastica は Borrmann 4 型スキルスの中に分類される特殊型であると簡明な説明 を行い著者らもこれに従った. linitis plastica は胃全体 を占居するむのであり，多くは胃底腺領域の II $\mathrm{c}$ 型未分 化癌から発生するといら説") (5)が本邦では大等を占める が，逆に胃前庭部から発生するとする説) るある. しか しながらこの型の癌では病変が胃全体にひろがっている らえに潰煬や隆起なと原発巣を推測させる部分が粘膜面 そみられないことが多く，発生母地を明らかに指摘する ことは困難であることが多い，著者等の例では巨大毁壁 に占居された前壁の胃底腺領域に浅いビランがありこの 部が原発坚と推測されたが，組織学的にはこの部を含め 胃底腺创域には結合織增生の強い固有筇層の中に，变性 した印環細胞と思われる細胞が非常に䟽にみられるのみ であり，巨大媇壁のない幽門腺領域と线いビランのある 噴門腺〜食道粘膜面に印環細胞群が密にみられ，漠へ 浸潤している.すなわち原発画である率が高いといわれ る胃底腺領域には明膫な癌病巣はすくなく，その口肛側 に密な癌病巣がみらられる。噴門腺，食道に癌病巣がなけ れば糹門腺領域が原発であり胃底腺領域粘膜下，固有笳 層に浸潤堌殖したとも考えられるし，幽門腺領域に癌病 单がなけれは噴門腺領域が原発巣とむ考えられる。本症 例では练壁の肥大や粘膜の肥厚，結合織の增生のある部 分および癌病巣の不明瞭な部分は胃底腺領域のみである ことから，癌の発生とその浸潤增殖の時間的推移によっ て，吉井 ${ }^{2)}$ の述べるよらに，この部ではやがて増殖した 結合識,膠原線維の中に癌細胞か変性崩罗して減少し, 残存した癌細胞も萎縮が強く結合織細胞や资性細胞と区 別がつきにくくなっているとすれば，やはり胃底腺領域 のこのような変化が時間的に最も古い癌発生の場，すな わち原発鉴であるが故にみられる変化と考えることも出 来る. このように linitis plastica の定義の一つに胃全体 に拡ったものといら条件が加えられれば，その原発巣の 確認は極めて困難と思われる。

Brenner 腫瘍は1898年 MacNaughton-Jones により 最初に multiple fibromatous mass として報告され”， 1907年 Fritz Brenner が自験 3 例に他の報告例を加えて Oophoroma folliculare として報告して以来その名称か： あるといわれる゙9?. estrogen production を暗示する例 むいくつかあるが大多数は inert であり無症状であっ 
て，90〜95\%は他の手術に際し偶然に発見される ${ }^{920)}$. 自験例のよ弓に術前の膀脱造影によってその尰㾿として の存在が推測された例は稀と思われる. その起源につい ては諸説があり, Walhard-明城細胞由来とする報告が多 いよらであるが定説はない５0歳台の女性に頻度が高 く, Krukenberg 腫湯を除く卵巣充実性腫場の1.7\%の頻 度と報告され，多くは片側性である ${ }^{11212)}$. Lamping 等》 は世界の500例以上の報告の中で両侧性であった例は3.7 〜8.0\%としている. 組織学的には非常に特徵のある所 見を呈し，豊富な線維性結合織の中に上皮由来細胞力泒 立散在性にみとめられ，上皮細胞性ちるいは種々の移行 像と思われる龃胞を形成しており，他の疾患との組織学 的鑑別は容易である.上皮の増殖の程度る種々にみら れ，中には悪性との鑑別が困難な例むある．悪性と猃断 されたものでも多くは転移や再発はなく良好な経過をと る. Brenner 脳場の悪性化の報告は1945年 Von Numers の報告にはじまるが malignant Brenner Tumor として 報告されている例の中には良性と判断してるよい上皮増 殖型のものがかなり含まれて括り，これが予後の良好な 理由の1つになっているともいわれる(13)14). 本腫湯は他 の手術に際し偶然発見されるものが多いことは先に述べ たが，自験例のよらに胃癌例に併存した例は非常に稀と 考えられる. 卵巣の充実性腫痬では Krukenberg 腫痬が 最も頻度が高く $21.3 \%$ 頻度とされるが，その原発巣は $90 \%$ 以上が胃癌であり ${ }^{12)}$, Borrmann 4 型が多い. 本症 例む Borrmann 4 型の linitis plastica 型であり組織型 は印環細胞癌であり Krukenberg 腫湟の発生の可能性は 他に比べて高い，他に Brenner 腫瘍の外観が悪性腫渲に わ類似していたこと. Brenner 腫瘍の経験がなかったこ とから本症例では片側性にきた Kurkenberg 腫瘍と判断 した，幸いにも腫瘍を切除し，胃癌に対してる全摘術に $\mathrm{R}_{3}$ の廍清を付加しており，Brenner 腫場と判朋したの ちに再開腹, 根治手術を追加する必要性を逸れた，䏴癌 手術に際して Krukenberg 腫瘍のみられる頻度は 1 20 $\%^{12)}$ とされるが，他の充実性腫湯のみられる頻度は不明

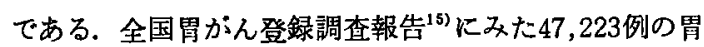
癌症例のうち卵巣，畉管乱よび子宮広間膜のいずれかに 癌を重複したとの報告は11例のみであり，何らの原因で 卵巣切除を合併された例は食道，肝，脾，副霄，脾ら を除いた他荿器合侀切除例に含弯れると思らがこれ は0.61\%であり，卵栄のみの合併切除頿度は更に低い あのと思われる，すなわち胃癌国である 本邦において Krukenberg 腫場の頻度は近年低下しているとも考えら
れあるいは Krukenberg 尰瘍合併症例は切除の対象に ならないとされることがこの様に嚬度の低いことの一つ の原因であるとすれば，これらの腫鈞の中に Brenner 尰 瘍が含まれてしまうことのないよらに注意する必要があ ろう.

\section{まとめ}

Brenner 腫瘍を経験した. 自験例は linitis plastica 型 胃癌例に併存したわのであったため，初め Krukenberg 腫瘍と判断したが Brenner 腫瘍であったため非治瘾手術 が一転して治症手術になったるのである. Brenner 隀瘍 は卵巣の充实董瘍の中です稀なるのであるが，胃癌，と $く に$ linitis plastica 型胃癌例に見出された症例の文献的 報告はまだみられない. linitis plastica 型胃癌, Brenner 腫瘍，䏴癌と卵巣尰瘍の併存頻度などについて若干の知 見を加えて報告した。

\section{文 献}

1) 第29回胃癌研究会 : スキルスの病理, 日癌治, 13, 6, 86-98 1978.

2) 吉井隆博：スキルスの概念と組織発生，胃と腸 11, 10, 1297-1305, 1976.

3) Nagayo, T. and Yokoyama, T.: Scirrhous carcinoma occuring in the corpus (body) of the stomach. Acta Path. Jap., 24: 794—814, 1974.

4) 中村恭一, 营野晴夫, 丸山雅一ほか：linitis plastica の原発巣についての病理組織学的研究. 胃と腸, $10: 79-86,1975$.

5) 渡辺英伸，八尾恒良 : linitis plastica 型胃癌の 病理組織学的研究, 胃と腸, $11,10,1285-$ $1296,1976$.

6) Saphir, O. and Parker, M.L.: Liniti plastica type of carcinoma. Surg. Gynec. Obstet, 76 : 206, 1943.

7) Lawrence, D.: Uterine fibroid with anomalous ovarian tumor. Am. J. Obstet. Gynecol., 15: $4271-4272,1978$.

8) Brenner, F.: Das Oophoroma Follculare. Frankfurt. 2. Path., 1: 150, 1907.

9) Lamping, J.D. and Blythe, J.G.: Bilateral brenner tumors, a case report and review of the literature. Hum. Pathol., 8, 5: 583-585, 1977.

10) Balasa, R.W., Adcock, L.L. and Prem, K.A.: The brenner tumor. A clinicopathologic review. 
Obstet. Gynecol., 50, 1: 120-128, 1977.

11) 石川栄世 : 尰湯病理学, 朝倉書店, 東京, 633 $634,1970$.

12）宮地 徹：臨床組織病理学, 杏林書院, 東京, 645 , 昭51.

13) Hsing Chang, S., Roberts, J.M. and Homesley, H.D.: Proliferating brenner tumour. Obstet.
Gynec., 49, 4: 489-493, 1977.

14) McKenna, H. and Ansford, A.: Malignant brenner tumour. Aust. N.Z.J. Obstet. Gynaec., 16, 4: 244-248, 1976.

15）全国胃がん登録調查報告: 第 1 号 第 9 号, 胃 癌研究会, 国立がんセンター。 